\title{
Profile of Victims of Neighbourhood Crimes in Ghanaian Cities
}

\author{
Ernest Bagson ${ }^{1 *}$ \\ Adobea Owusu ${ }^{2}$ \\ George Owusu ${ }^{2}$ \\ Charlotte Wrigley-Asante ${ }^{3}$ \\ Martin Oteng-Ababio ${ }^{3}$
}

\begin{abstract}
Generally, urban crime research in Ghana is non-ambiguous on the socio-cultural, political economy and environmental ramifications of neighbourhood crimes in emerging cities, but the personal and neighbourhood level characteristics of the most likely victims of neighbourhood crime in Ghanaian cities remain meagre. This paper fills the gap in knowledge by answering the question 'who/where is the most likely victim of crime in urban Ghana?' This study employed a sequential mixed methods approach to collect data through the administration of a household survey, as well as focus group discussion (FDG) sessions. The survey data were analysed using binary logistic regression while the qualitative data were analysed using thematic analysis. The study found that socio-demographic characteristics, which are associated with a higher likelihood of victimisation, include young unemployed persons, residents of a detached or 'self-contained' apartment, household of increasing household size, residents of neighbourhoods with less police visibility and residents of unsafe neighbourhoods. Cognisance of the limited capacity of the Ghana Police Service, this study recommends the need for the Ghana Police Service to consider neighbourhood demographic characteristics in their efforts to enhance distributive justice in the provision of internal security.
\end{abstract}

Keywords: Crime, victim, urban, socio-demographic characteristics, Ghana

${ }^{1}$ Department of Local Governance and City Management, SD Dombo University of Business and Integrated Development Studies, Wa, Ghana; ${ }^{2}$ Institute of Statistical, Social and Economic Research, University of Ghana, Legon; ${ }^{2}$ Department of Geography and Resource Development, University of Ghana, Legon. *Corresponding author email: ebagson@ubids.edu.gh

Ghana Journal of Geography Vol. 13 (2), 2021 pages 1-30

https://dx.doi.org/10.4314/gig.v13i2.1 


\section{Introduction}

Urban crime has implications for a plethora of socio-economic and general development issues such as public safety, residential and community development, service delivery and governance, socio-structural, and urban policy formulation and implementation. Since Ghana's population became more urban (50.9\%) than rural (49.1\%) in 2010 (Ghana Statistical Service (GSS) 2012), urban security issues and the general quality of life within the urban space has attracted practical and policy concerns. Nevertheless, the few emerging studies on crime in Ghana focus contextually on the economic and socio-structural metamorphosis that underpin the events of crime (Appiahene-Gyamfi, 2003; Bagson \& Owusu, 2016; Oteng-Ababio, 2016; Owusu et al., 2016; Owusu et al., 2015; Tankebe, 2013). Despite the relevance of earlier crime research in Ghana, limited attention is given to the basic question of "who is a typical victim of crime or where do crime commonly occur in urban Ghana?"

Some earlier scholarly works on victimisation by GSS (2010) and Sulemana (2014) cannot be ignored despite their limitations on providing adequate attributes of the most likely victims of crime. For instance, whilst GSS (2010) focused on the rate of victimisation, experiences of victims, fear of crime and general crime prevention strategies in Ghana, Sulemana's (2014) findings centred on fear of crime and crime victimisation in Africa. In the works of GSS (2010) and Sulemana (2014), the paucity of data on personal characteristics of the respondents limited their efforts to predict the most likely prey of crime in Ghana and Africa, respectively. This lacuna defeats the fundamental principle that "crime prevention starts with knowledge" (Malby, 2011, p.79). Knowledge on the most likely victims adds to the general practical and policy efforts towards crime prevention, particularly in the region of sub-Saharan Africa, which has record high 
crime victimisation in recent times (Di Tella et al., 2008; Oteng-Ababio et al., 2016; Umar et al., 2020).

In Ghana, most recent media reports and academic studies (Abudu, Nuhu, \& Nkuah, 2013; Frimpong, 2016; GSS, 2010; Owusu et al., 2016b) have captured a heightened sense of fear of crime, and crime victimisation among the public within the Ghanaian urban space. The victimisation survey (GSS, 2010) in the four most urbanised cities in Ghana (Accra, Kumasi, Sekondi-Takoradi and Tamale) documented varied levels of fear of crime as expressed by individuals at the community (35\%) and home (20\%) levels when alone after dark. In addition, 56 percent of the households studied indicated the possibility of being burgled within 12 months after the survey (GSS 2010). These underscore the need for crime prevention and control strategies in a country of limited police capacity (Bagson, 2018; Owusu et al., 2015; Tankebe, 2008), while minimising incidences of inequality in access to the state security services (Bagson \& Owusu, 2016; Bagson, 2018; Wrigley-Asante et al., 2016).

This study seeks to explore individual and neighbourhood level characteristics that describe the most likely crime victims in Ghana's urban space through the lenses of crime victimisation theories. It links theory to practical situations by interrogating how the immediate neighbourhoods of urban dwellers support or prohibit crime or victimization in urban Ghana. It fills the gap in knowledge by answering the question "who is the typical victim of neighbourhood crime in Ghanaian cities?" More specifically, the study examines how the demographic characteristics of urban dwellers and the characteristics of their dwelling environments determine neighbourhood crime victimization. Knowledge on the most likely victims of crime will contribute to enhancing distributive justice of the limited police service within urban Ghana. Findings from this study could help mitigate the incidence of inequities in access to security services; and limit the unequal 
distribution of potential victims of crime as posited by some scholars (see Mellgren 2011; Moser 2004; Wrigley-Asante, 2016). It will also, uphold the importance of ecological influences on crime victimisation (see Oteng-Ababio et al., 2016; Owusu, et al. 2015).

\section{Victimisation Theories}

Theories explaining risk of victimisation reached the frontline in the field of criminological theories since the last quarter of the twentieth century (Meier \& Miethe 1993; Spano \& Freilich, 2009) and continue to enhance the understanding of risk of victimisation in the twenty first century (Pratt \& Turanovic 2016). Two dominants but quite related theories of victimisation got immense currency since the last quarter of the twentieth century. The Lifestyle-Exposure Theory (LET) (Hindelang, Gottfredson, \& Garofalo 1978) and Routine Activity Theory (RAT) (Cohen \& Felson 1979; Felson \& Boba 2010) ameliorated keen perspectives on criminogenic opportunities in tandem with structural and social changes in human development history. Some scholars use the two theories simultaneously or interchangeably (Pratt \& Turanovic 2014; Wilcox et al. 2014).

Nevertheless, a critical review reveals difference between the two with respect to the conceptualization of the risk of victimisation. While LET emphasises the probability associated with risk of victimisation in time and space, (Hindelang et al., 1978), RAT conceptualises risk of victimisation as an event in which the absence of one of the three minimum requirements of crime (motivated offender, a suitable target and absence of capable guardian) converges within time and space, and results in the occurrence of crime (Cohen \& Felson 1979; Felson \& Boba, 2010).

Lifestyle-Exposure Theory (LET) is proposed by Hindelang et al. (1978). The theory attempts to relate risk of victimisation to individual lifestyle-exposure, and notes that demographic characteristics, as a common precursor of lifestyle, vary with risk of victimisation. Hindelang et 
al. (1978, p. 241) operationalised lifestyle as "routine daily activities, both vocational activities (work, school, keeping house, etc.) and leisure activities." Depending on the kind of daily routine, an individual may by virtue of his/her lifestyle be exposed to higher risks than others.

Since its postulation, the LET has attracted wider operationalisation and application in different fields of research (Meier \& Miethe, 1993; Vakhitova, Reynald, \& Townsley, 2016). For instance, Meier and Miethe (1993) indicate that the theory was initially proposed to gauge the risk associated with violent crime among people of similar social identity. In most common analytical situations of risk of victimisation, the level of exposure to risk is directly or indirectly influenced by obligatory social roles or some limitations with respect to the economic status or educational level, income or some subcultural obligation as well as discretionary potencies engendering one's daily life (Holtfreter et al. 2008). This means that, daily lifestyle activity depicts the level of risk of exposure of persons and properties, and variations of victimisation.

However, some scholars have drawn attention to some limitations of the lifestyle-exposure theory. Garofalo (1987) pointed out its inadequacy in fully explaining variation in risk of victimisation per individual socio-demographic differences. This provokes the need to examine other factors associated with lifestyle and demographic variation influencing the process of victimisation in the Ghanaian urban space. Vakhitova et al. (2016) also questioned the applicability of Lifestyle Exposure Theory in different territory such as in the cyber environment. Thus, in most scientific discourses, the influence of the Lifestyle Exposure Theory to understanding risk of victimisation, within fast urbanising cities characterised by largely informal sector, as in developing countries, is scarce (Messner et al. 2007).

Routine Activity Theory: Postulated by Cohen and Felson (1979), the risk of victimisation was conceptualised as an event in which a motivated offender, suitable target and the absence of a 
capable guardian converge within time and space for a crime to occur. According to Cohen and Felson (1979), complexities underlying social and economic dynamics within the immediate environment induce or deter the occurrence of crime within time and space. This is in spite of Reyns, Henson, and Fisher's (2011, p. 1122) findings that "possible absence of an intersection in time between victims and offenders within networks" equally benefits from routine activity theory. Thus, in the pursuance of the social and economic activities as a way of life, peoples' daily activities define the level of risk of victimisation within time and space.

In their operationalisation, the suitability of a target is dependent on the potential offender's perception of the value of the target, the ease of movement with the target, its ease of concealment and ease of access (Cohen \& Felson 1979). Target suitability is, therefore, a function of the reasoned judgment of the potential offender taking into consideration the security implications of the immediate environment. Thus, increase in the suitability of a target gives a corresponding increase in the risk of victimisation in consonance with Spano and Freilich (2009).

By extension, the capable guardian could be a person with the ability to prevent the occurrence of crime or physical mechanical installations such as closed-circuit television, barb wires, alarms, etc. which, with the support of a capable person, can limit the opportunity of the potential offender to access the target and therefore, serve as sources of demotivation to the offender (Cohen \& Felson 1979). Common guardians include vigilante groups, friends, guard dogs, neighbours and locks (Clarke \& Felson 2005).

In the application of RAT, some scholars are of the view that demographic characteristics have significantly influenced the theoretical understanding of the risk of victimisation within different spacio-temporal domains (Holtfreter et al. 2008; Pratt, Holtfreter \& Reisig, 2010; Reyns, 2013). For instance, Pratt et al. (2010) unravel how personal characteristics influence the risk of 
victimisation of internet users in Florida. Specifically, Reyns (2013) indicated that individuals who engage in internet banking, including e-mailing, were $50 \%$ more likely to be victims of theft between 2008 and 2009 in Britain. Furthermore, the prevailing social and ecological conditions of the immediate surroundings influence the discretion of a potential offender to commit crime or not. It, therefore, implies that a community closely knitted for a good cause (such as crime prevention) has a high potential to avert criminogenic tendencies from manifesting into eventful crimes (Spano 2005).

\section{Description of the study sites}

The four most urbanising cities in Ghana (Accra, Kumasi, Sekondi-Takoradi and Tamale) were purposively selected (Table 1) in pursuance of the overall national research objective: 'exploring the relationship between poverty and the incidence of crime in relation to the different socioeconomic characteristic of 12 neighbourhoods. Given the paucity of information on the details of victims of crime in Ghana's urban space, as articulated above, this paper found it expedient to focus on the demographic make-up of victims of neighbourhood crime, taking advantage of the large data set produced in the national study.

Apart from evidence of continuous natural increase in population within the four cities (GSS, 2013), the cities appear to be the most preferred destination of both local and international migrants (Awumbila, \& Ardayfio-Schandorf, 2008; Van der Geest, 2011). Collectively, they constitute about 40 percent of the total urban population in Ghana as of the last national census in 2010 (GSS, 2013) and, therefore, are places of active economic and industrial activities. Notwithstanding the generally peaceful nature of Ghana compared to other countries within the sub-Saharan region (Darkwa \& Attuquayefio, 2012; Global Peace Index, 2017), peculiarity in each cityscape accounts for variation in some incidence of crime and, therefore, compels the need to expose the distinctive 
predictable individual and neighbourhood level characteristics of victims of crime in the four cities.

Accra: Accra as the political and administrative capital of Ghana and the regional capital of the Greater Accra region makes it an incentive hub for increased complex human activities within time and space. Its complex self-organising and largely informal cityscape complements heterogeneously fluid socio-economic dynamics, which appear to induce and sustain criminogenic tendencies. As well, these characteristics fuel inequality in access to social services, including security services (Sewidan, 2015). In addition, Accra has been the least poor city in Ghana since the year 2000 (GSS, 2000, 2014; Sewidan, 2015), and, therefore, a suitable environment for the continuous interaction between motivated offenders and suitable targets. Accra's unique attraction for criminality is also explained by the demographic bulging of the middle class in urban Ghana. Thus, the socio-geo-economic settings in Accra have created a rife atmosphere for crime, fear, battling excessive traffic, and often, lack of meaningful social interactions for residents.

Kumasi: As the political and administrative capital of the Ashanti region, Kumasi has been the most populous city in Ghana (GSS, 2013). Once the 'garden city' of Ghana (Adjei-Mensah, 2014; Koranteng, 2017), the central geographic location of Kumasi, the relatively good transport networks within and connected to other regional capitals in Ghana, and its suitable multifaceted market place befits its industrial and economic vibrancy. These attributes have also branded Kumasi as a crime-prone city (Bagson, 2019), where there are major divides in several forms between affluent and dilapidated communities and their inhabitants.

Tamale: as the capital of the then northern territories in 1906 (MacGaffey, 2006), Tamale is still the largest city in northern Ghana (GSS, 2013). The city's spatial and demographic expansion is facilitated by relatively good road network within the cityscape, extending to the neighbouring 
regional capitals in Ghana and the Sahelian region of North Africa. Tamale is the fastest growing city in West Africa (Ziem, 2013). Further, its large informal commercial space, skills-trapped youthful population, and increasing middle class population, tickle minds about who the most likely victims of crime in the city could be, cognisance of the increase in reported cases of crime in the city (Ghana Police Service, 2014).

Sekondi-Takoradi: Sekondi and Takoradi are two co-joined cities of similar social, economic and political intricacies, often referred to as the twin-city in Ghana. The port cities are the administrative and political capital of the natural resource rich Western region and the site of the second largest harbour in Ghana. Recently, the urban economy and social structure of the twincity has been complicated by the discovery and extraction of oil off shore. Thus, the recent population heterogeneity and buoyant local economic and commercial activities in SekondiTakoradi need scholarly inquiry into who is likely to become victim of crime.

It is in these contexts of the socio-spatial and demographic characteristics, transformation and challenges, that these four most urbanised cities in Ghana attract all forms of seekers but also, vices, and have witnessed geometric increase in criminal activity over the last few decades (OtengAbabio et al., 2016). In each of the four selected cities, three neighbourhoods, of different socioeconomic characteristics were purposely selected (Tables $1 \& 2$ ). 
Table 1: Neighbourhood socio-economic status and sample size

\begin{tabular}{lllll}
\hline City & Neighbourhood & $\begin{array}{l}\text { neighbourhood } \\
\text { status }\end{array}$ & $\begin{array}{l}\text { No. } \\
\text { Selected EAs }\end{array}$ & $\begin{array}{l}\text { of } \\
\text { Sample Allocation of }\end{array}$ \\
\hline Accra & Airport Residential Area & Upper-class & 2 & 30 \\
& Dansoman & Middle-class & 20 & 300 \\
& Glefee-Dansoman & Low-class & 4 & 60 \\
& Nima & Low-class & 34 & 510 \\
Kumasi & Ahodwo/Nhyiraso & Upper-class & 4 & 60 \\
& Oforikrom & Middle-class & 31 & 465 \\
& Aboabo & Low-class & 24 & 360 \\
Sekondi- & Chapel Hill & Upper-class & 11 & 165 \\
Takoradi & Anaji Estate & Middle-class & 9 & 135 \\
& New Takoradi & Low-class & 14 & 210 \\
Tamale & Russian Bungalow & Upper-class & 3 & 45 \\
& Zogbeli & Middle-class & 15 & 225 \\
& Aboabo-Tamale & Low-class & 12 & 180 \\
Total & & & 183 & 2,745 \\
\hline
\end{tabular}

Source: Owusu et al. (2016)

\section{Qualitative analytic strategies}

Adopting an exploratory sequential mixed methods approach, qualitative data were first collected from purposive sampling of victims of crime and religious/community/opinion leaders residing in each of the three different neighbourhoods.

Table 2: Broad socio-economic neighbourhood characteristics in urban Ghana

\begin{tabular}{ll}
\hline *S-EN & Neighbourhood characteristics \\
\hline Low-class & High population density; poor infrastructure; low incomes and educational \\
& levels, multiple household apartments with shared facilities such as bathroom, \\
& kitchen, toilet etc.; unskilled labour force, and limited spatial planning. \\
Middle-class & Lower population density, evidence of some spatial planning obligations, better \\
& access to services than lower class residential areas; mostly one household per \\
& apartment; middle to high skilled labour force, among others. \\
High-class & Lowest population density, better access to services than the lower- and middle- \\
& class areas, better spatially planned and commonly one household in one \\
& apartment; occupants are largely middle- and upper- income persons; as well as \\
& high skilled labour force.
\end{tabular}

Source: adapted from Bagson, 2018; Owusu and Agyei-Mensah, 2011; Songsore and Goldstein, 2005.

Selected religious/community/opinion leaders were instrumental in the study because of the important role they play in caring for victims of crime within their jurisdiction, particularly in the 
current situations where access to the formal victims' support systems, such as the Ghana Police Service, is limited (Bagson, 2018). A pre-tested key informant interview guide and a focus group discussion guide was used to collect the qualitative data. A total of 12 religious/community/opinion leaders and ten victims of neighbourhood crime were interviewed as key informants in each of the four cities. The community leaders were purposively selected based on their leadership roles in the communities studied, their availability, and willingness to be interviewed. Led by the local Assembly Member (neighbourhood governance leader), victims of crimes were recruited for the key informant interviews through snowballing.

Additionally, three FGDs were conducted in each of the four cities. In each city, one FGD was conducted in each of the three selected socio-economic neighbourhoods. Criteria for inclusion in the FGD were based on being a family member of a victim of neighbourhood crime. Hence, a minimum of five and a maximum of seven family members of victims of neighbourhood crimes formed a focus group in each of the selected socio-economic neighbourhoods. The FGD participants were also selected through snowballing, based on their availability, and willingness to be part of the group discussions. Family members of the victims were deemed very important informants on exposing the routine activities and general life courses of victims of neighbourhood crime. A combination of both males and females were included in each focus group to enable a balanced narrative on individual and neighbourhood level characteristics that have the potential or have contributed to the incidence of neighbourhood crime victimisation. Each FGD lasted between 40 to 60 minutes. Key informants and FGD participants had to meet an additional criterion of either having been victimised or having had a close family member with whom one shares accommodation being victimised within six months from the day of interview. The time limit was 
to ensure that both the victims and their family members could more readily recall the victimisation event(s) and their effects on them.

All the interviews and FGDs, which were conducted in the widely spoken local languages or/and the English language, were audio recorded and transcribed. Debriefing meetings were always organised with participants as a quality check on the data and, therefore, enhanced close representation of the lived experiences of the research participants. This was immediately followed by generation of codes as the basis to initiate thematic analysis. The use of thematic analysis helped to put together and further elucidate the common experiences of the participants on issues of neighbourhood crime victimization.

\section{Quantitative analytic strategies}

Respondents of the survey were selected through multi-stage cluster sampling design. This sampling design enabled equal chances of inclusion of all household heads residing in each of the selected neighbourhoods. In conducting the multi-stage cluster sampling design, enumeration areas (EAs), which are the basic unit on which Ghana's 2010 population census was conducted, formed the primary-sampling units (PSUs) for each neighbourhood (Table 1). Preference was given to the use of EAs since the GSS has demographic data on households in each EA. Households then became the secondary sampling units (SSU) in each selected EA. The first stage of the sampling involved sampling of the EAs (PSU) based on probability proportional to size; hence, the number of EAs per city depended on the proportion of the city's population to the total population of the four cities. However, to permit intra-city analysis, the number of EAs in Tamale and Sekondi-Takoradi were over sampled because of their relatively smaller population of 371,351 and 559,548, respectively, compared to the populations of Accra (1.8 million) and Kumasi (2.0 million) (GSS, 2013). 


\section{Measures of variables}

Dependent variable: A dichotomous dependent variable was generated from a yes or no answer

to the question: "Have you or any member of your household ever been a victim of any crime?"

(Table 3).

Table 3: Codes of dependent and independent variables

\begin{tabular}{lll}
\hline & Codes & \\
\cline { 2 - 3 } Variables & Reference categories & Non-reference categories \\
\hline \multirow{2}{*}{$\begin{array}{l}\text { Dependent variable } \\
\text { Independent variables }\end{array}$} & Yes $=1$ & No $=0$ \\
Individual level characteristics & & \\
Period of residence & & \\
Age & Continuous variable & \\
Household size & Continuous variable & \\
Gender & Continuous variable & \\
Marital status & Male $=1$ & Female $=0$ \\
Occupational status & Married $=1$ & Not married $=0$ \\
Level of education & Employed $=1$ & Unemployed $=0$ \\
Average household income & Above high school $=1$ & High school $\&$ below $=0$ \\
Shared dwelling unit & 1,501 and above $=1$ & $1-1,500=0($ Cedis $)$ \\
Neighbourhood level characteristics & Yes $=1$ & No $=0$ \\
Safety & & \\
Youth disorder & Safe $=1$ & Not safe $=0$ \\
Need police & Problem $=1$ & Not a problem $=0$ \\
Willingness to intervene in a criminal act & Yes $=1$ & No =0 \\
\hline
\end{tabular}

Source: Field data, 2014

Secondly, with a random start in each sampled EA, 15 households were systematically sampled at regular intervals to obtain 2,745 household heads for all the four cities (Table 1). Specifically, the household head or a representative (an adult of more than 18 years old) was interviewed. However, simple random sampling was further done when a multiple household apartment was sampled. 
Automatic priority of inclusion was given to female household heads in multiple household apartments to offset the male dominant (65\%) situation of household headship in the Ghanaian context (GSS, 2013). The quantitative data was subjected to binary logistic regression analysis as outlined in the next section.

Independent variables: a mixture of continuous and categorical field data of individual, household and community levels variables were the constituents of the set of independent variables (Table 3). Whilst individual level variables such as age, household size and period of residence were collected from respondents as continuous variables, other variables such as sex, marital status, and maximum level of education, average household consumption, income and type of dwelling unit were categorical variables. Neighbourhood level variables such as level of crime, perceived neighbourhood safety, and whether youth disorder is a problem were categorical variables whereas social cohesion among neighbours was a composite variable created from a five-item Likert scale. The Likert scale items are derivatives of Sampson et al.'s (1997) multilevel study of collective efficacy in crime control and prevention.

Items of the Likert scale measuring social cohesion and trust included the following statements, of which respondents were required to choose from strongly agree to strongly disagree: this is a closeknit neighbourhood, people in this community generally do not get along with each other, people in this community can be trusted, neighbours are willing to help one another and people in this neighbourhood do not share the same values. Since the items are a mixture of positive and negative statements, all negative statements were reversed to positive statements so that an increase in the mean value of the composite variable results in an increase in social cohesion (Pallant, 2013). This was supported by a Cronbach's alpha value of 0.79 , which suitably converged composite variable construction requirements (Pallant, 2013). 


\section{Evaluation of the analytic model}

Having established the relevant variables due for the binary logistic regression analysis, the model was evaluated to gauge its predictive potentials in estimating the likelihood of an individual's victimisation at the individual and neighbourhood levels in the cities of Accra, Sekondi-Takoradi, Kumasi and Tamale. Some basic evaluation tests were conducted. Firstly, collinearity test indicated the likelihood of multicollinearity among the independent variables using measures of Tolerance and Variance Inflation Factor (VIF). Whilst the Tolerance value explains the extent to which varying one independent variable is not explained by the other independent variables in the model, VIF is the inverse of the Tolerance value (Pallant, 2013). Hence, a Tolerance value of less than 0.10 (or VIF greater than 10) intimate high-level correlation between the measured independent variables. Whilst there was a high correlation (the least being 0.68) between the dependent and independent variables in this study, the recorded Tolerance value of $0.71(\mathrm{VIF}=$ 1.41) suggests no significant multicollinearity among the independent variables.

Secondly, the suitability of the overall model was determined with reasons in sync with Peng et al.'s. (2002) concept of better-fit model. Peng et al. (2002, p. 5) posits that "a logistic model is said to provide a better fit to the data if it demonstrates an improvement over the intercept-only model". In this model, the intercept-only model fittingly classified 54 percent of the cases. However, the classification test in which all the independent variables were in the model correctly classified 73 percent of the cases. This implies that, the higher proportion of classification by the full model (73\%) is an improvement of the intercept-only model (54\%), and therefore suggests that the model is fit for the analysis. Thirdly, the coefficient of the Omnibus test of the model further confirms the model as best fit for the analysis since the significant value was less than 0.05 (Chi-square value $=65.6 ; \mathrm{df}=14 ; \mathrm{p}<0.000)$. Nevertheless, the Hosmer and Lemeshow test further confirmed the model fitness since the significant value $(\mathrm{p}>0.05 ; \mathrm{df}=8$; Chi-square $=11.3$ ) was greater than 
0.05 in accordance with Pallant (2013). In addition, the Cox and Snell R Square and the Nagelkerke R Square values finally exposed the expediency of the model. The R Square value is the "pseudo R square statistics" as posited by Pallant (2013, p.167) and it indicates the magnitude in which variation in the dependent variable is explained by the independent variable. Hence, the Cox and Snell R Square value of 0.33 and the Nagelkerke R Square value of 0.46 indicates that 33 percent to 46 percent variation in the dependent variable is adequately explained by the independent variables. Having established the appropriateness of the model, the data were analysed using SPSS version 22. The results, discussion, and conclusions follow in the next section.

\section{Results and discussion}

Our focus has been to unearth the profile of the typical neighbourhood crime victim in Ghana's four largest cities. We also highlight instances where our study found support for the crime victimisation theories adopted for this study. These four cities form $40 \%$ of the country's urban population in the 2010 and over $44 \%$ in the 2000 censuses, respectively. Previous research yielded scant known intellectual efforts on the question of "who is most likely to fall prey to crime victimisation in urban Ghana?" against the background of the fairly well-known increasing crime rates in urbanised communities in the country (Abudu et al. 2013; Oteng-Ababio et al. 2016).

\section{Demographic characteristics of respondents}

Environmental and individual level characteristics are very important determinants of both victims and perpetrators of crime as postulated by mainstream victimisation theories (such as Hindelang, et al., 1978; Cohen \& Felson 1979) and other scholars (see Bagson \& Owusu, 2016; Owusu et al., 2016). However, limited knowledge on the characteristics of victims of crime in Ghana makes this study relevant. Knowledge of these characteristics helps focus specific crime prevention strategies 
on particular individuals and environments taking cognisance of the fact that the appropriate knowledge significantly accounts for some successes in crime prevention (Malby, 2011). In order to determine the relevant contributions or probability of particular attributes associated with victims of neighbourhood crime, results of the binary logistic regression as well as narratives of the respondents' experiences appeared useful.

As indicated in Table 4, the majority of respondents $(61 \%)$ indicated that neither they nor their immediate family member has ever been a victim of crime within the last six months to the date of the data collection. This confirmed findings by some scholars who described Ghana as the most peaceful nation within sub-Saharan Africa, despite the general instability in the sub region (Darkwa \& Attuquayefio, 2012; Global Peace Index, 2017). Notwithstanding the public cynicism on the ability of the Ghana Police Service to fight crime, 63.3 percent of victims of crime reported to the Police with the hope that the Police could be of help to them and the majority (56\%) appeared satisfied with the services provided by the police at the time they were victims of crime.

Subsequently, even though these descriptive statistics (see Table 4) did not differ so much from the national level situation (GSS, 2013), some predictors attracted attention. The majority (89\%) of our respondents are in some form of employment. An equally high proportion of the respondents (82\%) had a maximum of between basic and high school levels of education. Furthermore, 89 percent of the respondents had average household monthly consumption income of not more than 1,500 Ghana cedis ( 0.27 to 398.94 USD, October 2015). In addition, 40 percent of the respondents lived in multiple household apartments (Table 4). At the neighbourhood level, respondents generally felt safe $(82 \%)$. However, respondents' perception of youth disruptions in the community (47\%) or otherwise (53\%), were near equal proportions (Table 4). 


\section{Characteristics of victims of crime in urban Ghana}

At the individual level, four of the nine-predictor variables (age, household size, employment status, and living in shared dwelling unit) used in the logistic regression analysis appeared statistically significant determinants of being a victim of crime in urban Ghana (Table 5). The data indicate that with one-year increase in age, the odds of a person admitting being a victim of crime, is 0.064 times less likely. In other words, older persons were less likely victims of neighbourhood crime than younger persons were. A 63-year-old household head in Aboabo-Kumasi confirmed this through key informant interviews:

It is probably because I am now old and weak to defend myself that I am very careful of my personal security. I avoid known dangerous spots in the community, I stay indoors most of the time and I feel very safe in the community (63 years old, male, household head, Aboabo-Kumasi). 
Table 4: Descriptive statistics of individual and neighbourhood level characteristics

\begin{tabular}{|c|c|c|}
\hline \multicolumn{2}{|l|}{$\begin{array}{l}\text { Variables } \\
\text { Dependent variable }\end{array}$} & Percent (\%) \\
\hline Dependent variable & & \\
\hline \multirow[t]{2}{*}{ Victim of crime } & No & 61 \\
\hline & Yes & 39 \\
\hline \multicolumn{3}{|l|}{ Predictor variables } \\
\hline \multicolumn{3}{|l|}{ Individual level characteristics } \\
\hline \multicolumn{2}{|l|}{ Average period of residence } & $20^{*}$ \\
\hline \multicolumn{2}{|l|}{ Average age } & $40^{*}$ \\
\hline \multicolumn{2}{|l|}{ Average household size } & $5^{*}$ \\
\hline \multirow[t]{2}{*}{ Sex } & Male & 55 \\
\hline & Female & 45 \\
\hline \multirow[t]{2}{*}{ Marital status } & Not married & 42 \\
\hline & married & 58 \\
\hline \multirow[t]{2}{*}{ Employment status } & Not employed & 11 \\
\hline & Employed & 89 \\
\hline \multirow[t]{2}{*}{ Level of education } & High school and below & 82 \\
\hline & Above high school & 18 \\
\hline \multirow{2}{*}{$\begin{array}{l}\text { Average monthly household } \\
\text { income }\end{array}$} & $1-1,500$ cedis & 89 \\
\hline & 1,501 or more cedis & 11 \\
\hline \multirow{2}{*}{ Multiple household apartment } & No & 60 \\
\hline & Yes & 40 \\
\hline $\begin{array}{l}\text { Neighbourhood } \\
\text { characteristics }\end{array}$ & & \\
\hline \multirow[t]{2}{*}{ Safety } & Not safe & 18 \\
\hline & Safe & 82 \\
\hline \multirow[t]{2}{*}{ Youth disorder } & No & 47 \\
\hline & Yes & 53 \\
\hline \multirow[t]{2}{*}{ Needs police patrol } & No & 11 \\
\hline & Yes & 89 \\
\hline \multirow[t]{2}{*}{ Needs street light } & No & 14 \\
\hline & yes & 86 \\
\hline Social cohesion & & $13^{*}$ \\
\hline
\end{tabular}

Note: *mean values of the continuous variable

Source: Field data, 2014

It is, therefore, suggestive that younger people are more likely victims of neighbourhood crime in urban Ghana than older people are, which is in consonance with findings of Kanan and Pruitt (2002). On the predictive potentials of respondents' employment status on the likelihood of victimisation within the neighbourhoods of the Ghanaian urban space, the odds of a person or a 
family member being a victim of crime is 0.717 times less likely for someone who is employed than for the unemployed. This finding confirms similar studies in Ghana (Warner, 2011; Barnie, et al., 2017) that the most likely victims of crime are the unemployed youth who form a significant proportion of Ghana's population. Similarly, Baah-Boateng (2015) indicates that 7 in every 10 youth are unemployed in Ghana. This is indicative of a double burden on the youth, who are most likely victims of crime and likely unemployed but are the majority in the Ghanaian urban space.

Table 5: Predictor variables of victims of crime in the most urbanised cities in Ghana

\begin{tabular}{lccccc}
\hline Predictor variables & Odd Ratio & Std. Err. & P > z & 95\% Conf. Interval \\
\hline Individual level characteristics & & & & & \\
\hline Period of residence & 0.995 & 0.003 & 0.126 & 0.989 & 1.001 \\
Sex & 1.082 & 0.086 & 0.362 & 0.913 & 1.281 \\
Age & 0.064 & 0.003 & $0.018^{*}$ & 1.018 & 1.060 \\
Household size & 1.040 & 0.013 & $0.003^{*}$ & 1.013 & 1.068 \\
Marital status & 0.870 & 0.089 & 0.119 & 0.730 & 1.036 \\
Employment status & 0.717 & 0.144 & $0.021^{*}$ & 0.540 & 0.951 \\
Level of education & 1.182 & 0.114 & 0.141 & 0.946 & 1.477 \\
Average household income & 0.944 & 0.138 & 0.676 & 0.720 & 1.237 \\
Shared dwelling unit & 0.878 & 0.088 & $0.014^{*}$ & 0.539 & 0.844 \\
Neighbourhood level characteristics & & & & & 0.034 \\
Safety & 0.561 & 0.108 & $0.000^{*}$ & 0.454 & 0.694 \\
Youth disorder & 0.904 & 0.088 & 0.249 & 0.761 & 1.073 \\
Needs police patrol & 1.148 & 0.148 & $0.035^{*}$ & 0.559 & 0.834 \\
Social cohesion & 1.049 & 0.019 & $0.013^{*}$ & 1.010 & 1.089 \\
Needs street light & 0.852 & 0.124 & 0.194 & 0.668 & 1.085 \\
\hline Note: significant at 0.05 significant & & & & & \\
\hline
\end{tabular}

Note: *significant at 0.05 significant level.

Source: Field data, 2014. 
In Ghana, given the high statistics of unemployment among the youth (Baah-Boateng, 2015), our findings on employment and crime victimisation have share similarity in the sense that, the youth are exposed to both threats/risks of unemployment and crime victimization. A key informant attributed the connection between being youthful and crime victimisation to less supervision at home for the present-day youth, compared to what pertained some decades ago:

In recent times, parents and guardians are very busy with economic activities, mostly outside the home environment, to the detriment of offering guardianship to the young ones at homes (47-year-old, female, household head, Airport residential area, Accra).

\section{Neighbourhood characteristics and urban crime victimisation}

Furthermore, the study found that the odds of a person answering yes, he/she or a family member has been a victim of crime, is 0.878 times less likely for a person who lives in a multiple household house than someone who lives in a detached house or "self-contained house". This contravenes earlier research findings that incidence of crime is most likely in high population density areas than in low population density regions (Felson and Boba, 2010). They noted that the frequency and type of crime vary with population density. For instance, criminal offenses such as household larceny, burglary, personal theft and motor vehicle theft negatively correlate with high population density because of increased visibility (Decker et al., 1982; Felson and Boba, 2010). This is particularly the case in the low and middle socio-economic neighbourhoods where habitation of multi household apartments is common in urban Ghana. This makes a communal watch over the neighbourhood a typical strategy for lowering the potentials of victimisation as explained by a key informant in Nima-Accra:

The good thing is that, either consciously or unconsciously, there is always somebody at home all the times - at night and day break we sleep and wake up at different times respectively (45-year-old female household head, Nima-Accra). 
In other words, this study established that high population density residential areas have greater potential to reduce residential area related burglary. This is attributable to the high level of guardianship within such neighbourhoods as indicated by Cohen and Felson's (1979) conceptualization of the role of guardians in the Routine Activity Theory. This contradicts previous findings that the incidence of robbery and larceny increase with population density (Felson and Boba, 2010).

Nevertheless, our study found an important link between being housed in close proximity to one another and the probability of being a victim of crime. The odds of a person or a family member being a victim of crime is 1.040 times more likely as household size increases by one person in the four most urbanised cities in Ghana. This is not unexpected since the rate of contact-related crimes (such armed robbery, murder and assault) appear higher in high-density areas. For instance, Oteng-Ababio et al. (2016) in a longitudinal analysis of crime in Ghana indicates a continuous increase in aggregated decadal records of armed robbery cases as reported in both police data and key newspapers in Ghana.

In assessing police intervention in the course of crime, our study indicated that the odds of a person or a family member being a victim of crime is 1.148 times more likely for a person who requires more Police patrol in his/her residential community than a person who requires no Police patrol in his/her neighbourhood. This is in sync with the descriptive statistics in this study that the majority (63\%) of victims of crime reported the incident to the Police despite existing literature which indicates that in Ghana, there is low or non-reporting of crime to the Police (Felson \& Boba, 2010; Tankebe, 2013). Oteng-Ababio et al. (2016) had better explained the ancillaries to crime victims reporting the victimisation to the Police to depend on the type or severity of crime experienced. According to Oteng-Ababio et al. (2016), victims of crimes such as murder, rape, sexual abuse, 
and assault have higher rate of reporting because of the diverse trauma associated with such crimes. A key informant expressed similar opinion as follows:

I do not report all sort of crimes to the police; I consider the cost (money and time) of engaging the Police to the cost incurred by the victim (43-year-old key informant, male, Sekondi-Takoradi).

We also examined how social cohesion within neighbourhoods influences the potentials of victimisation. We found that with one-unit increase in social cohesion, a person is 1.049 times more likely to affirm that he/she or a family member has been a victim of crime within the community. This is in congruence with the conclusion at a focus group discussion in AboaboTamale where the members agreed that:

We live as a close-knit community but our efforts to act collectively to prevent crime is challenged by the increasing numbers of new settlements in the community (FGD, all male, Aboabo-Tamale).

Deductively, crimes within neighbourhoods are likely to be committed by acquaintances similar to the findings by Wrigley-Asante (2016). According to Wrigley-Asante (2016), close family members or neighbours commonly perpetrated crime such as rape and defilement. Hence, having established relationship between the perpetrator and the victim often leads to non-reporting of crime to the police or the intervening formal institutions. Instead, such in-house crimes are commonly resolved via reparation using informal means at the community level as opined by a community leader in Aboabo-Tamale. Thus, if familiarity appears to condone crime, we further examined how respondents' perception of safety within neighbourhoods influences the likelihood of victimisation. Our results indicated that the odds of a person affirming that he/she or a family member has been a victim of crime, is 0.561 times less likely for a person who perceives his/her neighbourhood is safe than someone who perceives his/her neighbourhood is not safe. Put in another way, feeling unsafe in one's neighbourhood had the higher odds of crime victimisation among the respondents/households studied. This finding corroborates Cohen and Felson's (1979) 
theorising that the potential for crime to occur is determined by the efficiency and effectiveness of the guardianship within time and space.

\section{Link between theories studied and our findings}

Our study also found some support for the theories we adopted vis-a-vis some empirical scenarios in our study communities. Notably, the last quarter of the twentieth century experienced a change in the global labour structure in which the hitherto housekeeping roles of women changed to adopt multiple livelihood strategies outside the home, which therefore limited the handler role of women on the behaviours of adolescents and the early youth cohort (Felson and Boba, 2010). In other words, in the absence of full-time parental control of the youth around the clock, more opportunities now exist, with the potential to stimulate and sustain the youths' vulnerability to being victims of neighbourhood crime than ever. On one note, the increasing use of technology in life's events has greatly caught up the interest of most youth. Moreover, advancement in the field of technology has gradually resized electronic gadgets that are now smaller and conveniently more concealable in recent times. It is on this basis that Cohen and Felson (1979) set forth the suitability of target as perceived by a potential offender within the principles of the Routine Activity Theory. This development magnifies the tendency of youth victimisation because of their rising interest in the use of electronic devices. This was highlighted by a key informant in the Tamale metropolis:

Reported cases of theft continue to lead other crimes in numbers. We commonly get such reports on market days and joyful events, in general, among the youth who are either offenders or victims in the pilfering of items such as phones, watches, laptops and other electronic devices and accessories (51-year-old senior Police Officer, male, Tamale).

Similarly, during a seven-member all female focus group discussion in Sekondi-Takoradi, discussants agreed that long hours of youth activities are unsupervised and therefore peer influence models their behaviours. In other words, the life exposures of the mostly unsupervised and 
unemployed youth in the Ghanaian urban space reflects the postulations of the Lifestyle Exposure Theory (Hindelang, et al., 1978) with regards to the tendency of victimisation and an individual life course.

\section{Limitations of the study}

In assessing neighbourhood and individual level characteristics of the most likely victims of crime in cities in Ghana, some limitations of the study cannot be ignored. Firstly, the broad conceptualisation of crime as used in this study limited the study's ability to predict victimisation by type of crime. Secondly, the findings lack generalisability to the non-urbanised parts of Ghana since the study was focused on cities in Ghana. These limitations notwithstanding, the study adds to the growing interest in crime studies in Ghana. Again, the findings support state security actors with empirical realities on the changing outlook of crime victimisation in urban Ghana.

\section{Conclusions and recommendations}

In a sequential mixed method approach, we unravelled who the most likely victims of crime in Ghanaian cities are. Our findings underscore the important effects of certain individual level variables (young unemployed persons, living in detached or 'self-contained' house, and increasing household size) and neighbourhood characteristics (perceived unsafe, limited police visibility, and increased 'perceived' social cohesion) as associated with more likelihood of crime victimisation. Thereby, we found support for the practical situations on ground in our study communities, and the theories we studied. The study recommends that the Ghana Police Service should prioritise individual and neighbourhood levels characteristics in their efforts to enhance distributive justice in the provision of internal security, cognisance of the limited capacity of the Police Service. This is particularly important given the inadequate police presence in Ghana generally (Bagson, 2018; 
Tankebe, 2008). Further studies on how Lifestyle Exposure Theory (Hindelang, et al., 1978) and the Routine Activity Theory (Cohen \& Felson, 1979) influence the situation of emerging cyber related crimes in Ghana is recommended.

\section{References}

Abudu, A.M., Nuhu, Y., \& Nkuah, K.J. (2013). Bridging the security gap in Ghana: The role of private security actors. Developing Country Studies, 3(10), 11-30.

Adjei-Mensah, C. (2014). Is Kumasi Still a Garden City? Land Use Analysis between 1980-2010. Journal of Environment and Ecology, 5(2), 89-107.

Appiahene-Gyamfi, J. (2003). Urban crime trends and patterns in Ghana: The case of Accra. Journal of Criminal Justice, 31(1), 13-23.

Awumbila, M., \& Ardayfio-Schandorf, E. (2008). Gendered poverty, migration and livelihood strategies of female porters in Accra, Ghana. Norsk Geografisk Tidsskrift-Norwegian Journal of Geography, 62(3), 171-179.

Baah-Boateng, W. (2015). Unemployment in Ghana: a cross sectional analysis from demand and supply perspectives. African Journal of Economic and Management Studies, 6(4), 402-415.

Bagson, E. (2018). Analysis of Informal Crime Prevention Strategies in Urban Ghana: The Case of Kumasi and Tamale: Doctoral dissertation, University of Ghana.

Bagson, E. (2019). Analysis of the spatial influence of the Ghana Police Service in the Kumasi Metropolis. International Journal of Current Science and Engineering, 1(7), 169-175.

Bagson, E. \& Owusu, A.Y. (2016). Securing the urban space: On who's terms? Insights from poverty and crime baseline survey in Tamale, Ghana. Ghana Journal of Geography, 8(1), 126149.

Barnie, A. J., Nyarko, A. S., Dapaah, J. M., Appiah, S. C. Y., \& Awuviry-Newton, K. (2017). Understanding Youth Violence in Kumasi: Does Community Socialization Matter? A CrossSectional Study. Urban Studies Research, 2017 (1), 1-10.

Basiago, A.D. (1999). Economic, social, and environmental sustainability in development theory and urban planning practice. The Environmentalist, 19, 145-161.

Brisson, D \& Roll, S. (2012). The effect of neighbourhood on crime and safety: a review of the evidence. Journal of Evidence-based Social Work, 9(4):333-350.

Byrne, J. (2009). Maximum impact: Targeting supervision on higher-risk people, places and times. Washington, DC: PEW Centre on the States. 
Cohen, L.E. \& Felson, M. (1979). Social change and crime rate trends: A routine activity approach. American Sociological Review, 44(4), 588-608.

Darkwa, L. \& Attuquayefio, P. (2012): Killing to protect? Land guards, state subordination and human rights in Ghana. Sur International Journal on Human Rights, 9(17):141-160.

Decker, D. L., Shichor, D., \& O'Brien, R. M. (1982). Urban structure and victimisation. Lexington, Mass.: Lexington Books.

Di Tella, R., MacCulloch, R. \& Nopo, H. (2008). Happiness and beliefs in criminal environments. RES Working Paper No. 4605. New York: Inter-American Development Bank.

Felson, M. \& Clarke, R.V. (2005). Opportunity Makes the Thief: Practical Theory for Crime Prevention. Police Research Series Paper 98. London: Home Office Research, Development and Statistics Directorate. Retrieved October 10, 2016 from http://www.homeoffice.gov.uk/rds/prgpdfs/fprs98.pdf.

Felson, M., \& Boba, R. L. (Eds.). (2010). Crime and everyday life. London: Sage.

Frimpong, L.K. (2016). Geography of fear of crime: Examining intraurban differentials in Sekondi-Takoradi Metropolis, Ghana. Ghana Geographical Journal, 8(1), 81-104.

Garofalo, J. (1987). Reassessing the lifestyle model of criminal victimisation. In M.R. Gottfredson \& T. Hirsch (Eds.). Positive criminology: Essays in honour of Michael J. Hindelang (pp. 2342). Beverly Hills, California: Sage.

Ghana Statistical Service (GSS) (2013). 2010 Population and Housing Census: National Analytical Report. Accra, Ghana: GSS.

Ghana Statistical Service (GSS) (2016). 2015 labour force report. Accra: GSS

Ghana Statistical Service (GSS). (2000). Ghana Living Standard Survey 4 - 1998. Accra: GSS

GPI (Global Peace Index) (2017). Measuring Peace in a Complex World. Sydney: Institute for Economic and Peace.

GSS. (2010). Victimisation survey in Ghana, 2009. Accra, Ghana: GSS/UN Office on Drugs and Crime (UNODC).

GSS. (2012). 2010 Population and housing census. Summary report of final results. Accra, Ghana: GSS.

GSS. (2014). 2010 population and housing census: district analytical report Accra Metropolitan. Accra: GSS.

Hindelang, M.J., Gottfredson, M.R., \& Garofalo, J. (1978). Victims of personal crime: An Empirical foundation for a theory of personal victimisation. Cambridge, MA: Ballinger.

Holtfreter, K., Reisig, M.D., \& Pratt, T.C. (2008). Low self-control, routine activities, and fraud victimisation. Criminology, 46(1), 189-220. 
Koranteng, A. (2017). Competitive Land Use/Cover of Kumasi and its Environs Based on Satellite Imagery Studies. In International Conference on Applied Science and Technology Conference Proceedings, 1(1), 208-219.

Landman, K. (2012). Stirring the urban pot: The nature and future of mixed housing in South

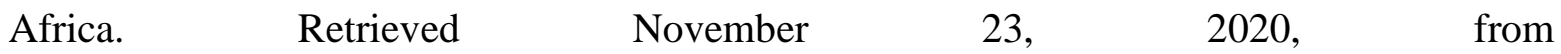
https://www.up.ac.za/media/shared/Legacy/sitefiles/file/44/1026/2163/8121/innovate7/stirri ngtheurbanpotthenatureandfutureofmixedhousinginsouthafrica.pdf

MacGaffey, W. (2006). A history of Tamale, 1907-1957 and beyond. Transactions of the Historical Society of Ghana, 10(2006-2007):109-124.

Malby, S. (2011). Understanding Urban Crime: Cross-national data collection. In M. Shaw \& V. Carli (Eds.), Practical approaches to urban crime prevention (pp. 79-83). Montreal: UNODC.

Meier, R.F. \& Miethe, T.D. (1993). Understanding theories of criminal victimisation. Crime and Justice, 17, 459-499.

Mellgren, C. (2011). Neighbourhood influence on fear of crime and victimisation in Sweden: A review of the crime survey literature. Malmo University Electronic Publishing. Retrieved February 19, 2016 from http://dspace.mah.se:8080/dspace/handle/2043/13063.

Messner, S.F., Lu, Z., Zhang, L., \& Liu, J. (2007). Risks of criminal victimisation in contemporary urban China: An application of lifestyle/routine activities theory. Justice Quarterly, 24(3), 496-522.

Moser, C.O.N. (2004). Urban violence and insecurity: An introductory roadmap. Environment \& Urbanization, 16(2), 3-16.

National Youth Policy of Ghana (2010). Towards an empowered youth, impacting positively on national development. Accra: Ministry of Youth and Sports.

Oteng-Ababio, M., Owusu, G., Wrigley-Asante, C., \& Owusu, A.Y. (2016). Longitudinal analysis of crime trends and patterns in Ghana (1980-2010): A new perspective. African Geographical Review, 35(3), 193-211, doi: 10.1080/19376812.2016.1208768.

Owusu, G., Oteng-Ababio, M., Owusu, A. Y., \& Wrigley-Asante, C. (2016). Can poor neighbourhoods be correlated with crime? Evidence from urban Ghana. Ghana Journal of Geography, 8(1), 11-31.

Owusu, G., Owusu, A. Y., Oteng-Ababio, M., Wrigley-Asante, C., \& Agyapong, I. (2016b). An assessment of households' perceptions of private security companies and crime in urban Ghana. Crime Science, 5 (1), 5.

Owusu, G., Wrigley-Asante, C., Oteng-Ababio, M. \& Owusu, A.Y. (2015): Crime prevention through environmental design (CPTED) and built-environmental manifestations in Accra and Kumasi, Ghana. Crime Prevention and Community Safety 17 (4):249-269.

Pallant, J. (2013). SPSS survival manual. London: McGraw-Hill Education. 
Pratt, T. C., Holtfreter, K., \& Reisig, M. D. (2010). Routine online activity and Internet fraud targeting: Extending the generality of routine activity theory. Journal of Research in Crime and Delinquency, 47, 267-296.

Pratt, T.C. \& Turanovic, J.J. (2016). Lifestyle and routine activity theories revisited: The importance of 'risk' to the study of victimisation. Victims \& Offenders, 11(3), 335-354.

Reyns, B.W. (2013). Online routine and identity theft victimisation: Further expanding routine activity theory beyond direct-contact offenses. Journal of Research in Crime and Delinquency, 50, 216-238.

Reyns, B.W., Henson, B., \& Fisher, B. S. (2011). Being pursued online: Applying cyber lifestyleroutine activities theory to cyberstalking victimisation. Criminal Justice and Behaviour, 38(11), 1149-1169.

Sampson, R.J., Raudenbush, S.W. \& Earls, F. (1997): Neighborhoods and violent crime: A multilevel study of collective efficacy. Science, 277:918-924.

Schreck, C.J., Wright, R.A., \& Miller, J.M. (2002). A study of individual and situational antecedents of violent victimisation. Justice Quarterly, 19(1), 159-180.

Sewidan, N. (2015). Poverty in Ghana's largest city. Retrieved March 18, 2018, from https://borgenproject.org/poverty-in-ghana-largest-city/.

Smith, S.J. (1987). Fear of crime: Beyond a geography of deviance. Progress in Human Geography, 11(1), 1-23.

Spano, R. (2005). Potential sources of observer bias in police observational data. Social Science Research, 34 (3), 591-617.

Spano, R., \& Freilich, J.D. (2009). An assessment of the empirical validity and conceptualization of individual level multivariate studies of lifestyle/routine activities theory published from 1995 to 2005. Journal of Criminal Justice, 37 (3), 305-314.

Sparks, R.F. (1981). Multiple victimisation: Evidence, theory, and future research. The Journal of Criminal Law and Criminology, 72(2), 762-778.

Sulemana, I. (2015). The effect of fear of crime and crime victimisation on subjective well-being in Africa. Social Indicators Research, 121(3), 849-872.

Tankebe, J. (2008). Police effectiveness and police trustworthiness in Ghana: An empirical appraisal. Criminology and Criminal Justice, 8 (2), 185-202.

Tankebe, J. (2013). In search of moral recognition? Policing and eudaemonic legitimacy in Ghana. Law \& Social Inquiry, 38, 576-597.

Turanovic, J.J. \& Pratt, C. (2014). 'Can’t stop, won't stop': Self-control, risky lifestyles, and repeat victimisation. Journal of Quantitative Criminology, 30 (1), 29-56. 
Umar, F., Johnson, S. D., \& Cheshire, J. A. (2020). Assessing the Spatial Concentration of Urban Crime: An Insight from Nigeria. Journal of Quantitative Criminology, 1-20.

Vakhitova, Z.I., Reynald, D.M., \& Townsley, M. (2016). Toward the adaptation of routine activity and lifestyle exposure theories to account for cyber abuse victimisation. Journal of Contemporary Criminal Justice, 32 (2), 169-188.

Van der Geest, K. (2011). North-South migration in Ghana: what role for the environment? International Migration, 49, e69-e94.

Warner, J. (2011). Understanding cyber-crime in Ghana: A view from below. International Journal of Cyber Criminology, 5 (1), 736.

Wrigley-Asante, C. (2016). Gendered perception of crime and safety: Insights from different socio-economic urban neighbourhoods in Ghana. Ghana Journal of Geography, 8 (1), 103123.

Wrigley-Asante, C., Owusu, G., Oteng-Ababio, M., \& Owusu, A. Y. (2016). Poverty and crime: Uncovering the hidden face of sexual crimes in urban low-income communities in Ghana. Ghana Journal of Geography, 8 (1), 32-50. 